\title{
Export experience and key success factors in cross- border trade: Evidence from Southern Africa
}

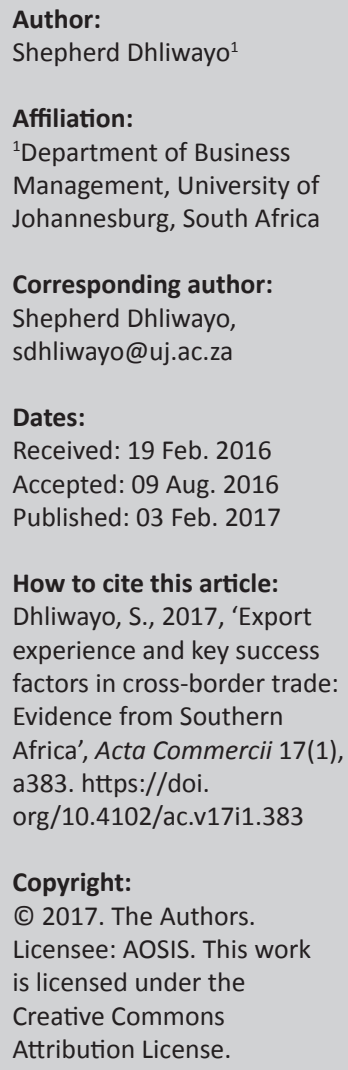

Orientation: Cross-border trade (CBT) is an important economic activity that contributes to the development of many economies of the developing world.

Research purpose: The two primary aims of the study were to find out the major factors needed to succeed in cross-border trading and whether the importance of these factors significantly decreased with export experience.

Motivation for the study: The economic contribution of cross-border trade (CBT) is often understated. As a result, it does not get the attention it deserves.

Research design, approach and method: Data were collected in Gauteng from 146 crossborder traders from 10 Southern African Development Community (SADC) countries. A crosssectional research design was used.

Main findings: The major key success factors were found to be skills/knowledge in; markets and supplies; financial management; and border issues. The importance of these factors was found to not significantly change with levels of export experience.

Practical/managerial implications: Stakeholders should know that small firms of differing export experience require the same interventions to succeed. Interventions should empower traders to better access markets and supplies, improve their financial management skills and ease border constraints.

Contribution/value-add: Few studies on cross border trading have been carried out in the Southern African Development Community region. The key success factors and the constraints in this type of trade had not been adequately explored. The economic contribution of CBT, which usually goes unnoticed, was highlighted. Interventions to appropriately address the challenges faced, such as trading legitimacy and border harassment, were suggested.

\section{Introduction}

Cross-border trade (CBT) is an important form of trade in many developing economies of the world. For example, though CBT in Central Europe decreased at the end of the 1990s when these countries joined the European Union, in South-Eastern Europe and Central Asian countries it is still a prominent pattern of entrepreneurship (Egbert 2006). Egbert (2006:348) refers to CBT as a 'mass phenomenon', which, though well researched or analysed by anthropologists and sociologists is largely ignored by economists and entrepreneurship researchers (Bernard et al. 2003). In 2016, the situation has hardly changed. Studies cover mainly formal small and medium-sized exporting firms, but not cross-border traders that are considered informal. This lack of interest is surprising given the importance of this trade in many economies. As pointed out by Eder, Yakovlev and Çarkoglu (2003), CBT in Eastern Europe is worth billions of dollars, and as reported by Southern Africa Trust (2008), the value in the Southern African Development Community (SADC) region averages US\$ 17.6 billion annually. Chiwara and Ndiaye (2010) and Unwomen.org (2010) assert that it contributes $30 \%-40 \%$ to intra-SADC trade. This is contradictory to what Bernard et al. (2007:3) state, that 'small firm exporting is relatively rare'. From the figures provided and from observations by (Unwomen.org), it can be concluded that CBT is an important economic activity contributing to the economic growth and government revenues of many economies.

The export and import of goods and services by small, micro and medium enterprises (SMMEs) is usually referred to as cross-border trade (CBT) (Egbert 2006; Tchouassi \& Njikam 2011). Operations are at times informal in nature and the entities involved are usually small in size. The Southern African Research \& Documentation Centre, SARDC.Net (2008) and Amornkitvikai, Harvie and Charoenrat (2012) note that CBT is usually limited to countries nearby, though it may have a global outreach in some cases. 
Though CBT addresses important livelihood issues, its contribution to the different economies appears to be neglected by mainstream trade policies and institutions, thereby undermining its visibility and profitability (Ama, Mangadi \& Ama 2014). If it was developed, it would empower traders and contribute to intra-African trade and regional integration (Chiwara \& Ndiaye 2010). This is supported by Soontiëns (2002), who notes that trade, especially between other SADC members and South Africa, is a key platform for social and economic development and regional integration. CBT involves the physical movement of not only goods but also people (the traders) and this contributes to social and economic interaction. For example, the Zimbabwean government's ban on imports of certain basic goods in June to July 2016 led to violent protests at both the South African and Zimbabwean sides of the Beit bridge border post. The border was closed for the first time in over a hundred years (The Citizen 2016). The International Cross-border Traders Association threatened to close down the Beit bridge boarder again if the Zimbabwean government did not lift its ban on imports of basic goods (Manyathela 2016). The bans threatened the livelihoods of the traders and survival of many related businesses in both countries, hence the protests.

It is only a portion of the more successful enterprises that go into the import and export business. They are then able to exploit bigger markets and derive higher profits while the less successful ones operate in the local market or close shop (Ottaviano \& Martincus 2011). If these exporters and importers survive the initial 5 years of operations, the implication is that they would be doing certain things right (Damijan, Polanec \& Prašnikar 2007; Esteve-Pérez, RequenaSilvente \& Pallardó-Lopez 2013). Bernard et al. (2003) and Melitz (2003) show that only the most efficient enterprises succeed to enter the export markets, and as shown by Muûls and Pisu (2009), cross-border traders outperform non-export traders. As shown in literature, cross-border enterprises in the same industry and of a similar size tend to be relatively better endowed in resources than domestic ones. Those firms that have been exporting for a longer period are expected to be more efficient. They are expected to successfully compete in the external markets because of long-established networks and experience. They are likely to be more efficient than younger firms as a result of their experience in learning by doing (Jongwanich \& Kohpaiboon 2008). Many researchers claimed that export age or experience improved performance through the enhanced ability to solve export problems and exploit opportunities over time (Ayan \& Percin 2005).

The aim of the study was to find out if the importance of (1) skills and assistance in CBT and (2) the major constrains faced decreased with a firm's experience in cross-border trading. As a result of the sizes of the firms under study, the owners' experience in trading and the firm's export period cannot be easily separated. This study approaches CBT from a constructivist view of formality. It is difficult to categorise the traders either as 'formal' or as 'informal'. This, according to Devey and Valodia (2009) is formality and informality linked together, as a continuum and not as dichotomies. This means that the cross-border traders meet some legal export or import requirements such as declaration of wares, but may under-declare the values in order to avoid or minimise paying duty. Therefore, the extent to which a trader is formal or informal cannot be easily ascertained. The issue of formality is an important factor in CBT because it is a source of the constraints traders face such as harassment by government agencies or the lack of support by governments.

The other aim of the study was to establish what was most important: (1) skills, (2) type of assistance needed to succeed in CBT or (3) constraints faced in CBT. The question is, do the importance of these key success factors significantly change with the trading experience? A literature review is presented first, the methodology next, then the results. Policy and application implications are presented last before the conclusion.

\section{Literature review and the set hypothesis}

There are many cross-border businesses. This study will focus on CBT by SMMEs. CBT by SMMEs is normally considered informal because the goods are not always moved through the formal trade channels (SADC Today 2008; Tchouassi \& Njikam 2011), and small consignments are often sourced and traded in informal sector markets mainly by individual traders (Lesser \& Moisé-Leeman 2009). Though CBT is an important economic activity, it is unfortunately often stereotyped as smuggling and is stigmatised (Chiliya, Masocha \& Zindiye 2011; Tchouassi \& Njikam 2011). It also lacks reliable data as a result of its informality (SADC Today 2008). In spite of this lack of data, CBT's contribution to total intra-SADC trade is estimated at between $30 \%$ and $40 \%$. Therefore, the regional body's member states could be overlooking an important component of their economy by ignoring these traders (SADC Today 2008).

According to Haltiwanger, Ron and Javier (2013) and Facundo et al. (2010), young firms are more volatile as they grow faster and as a result have short life spans. They typically start small, and in the second year, start exporting bigger volumes by expanding into newer markets or exporting new products. The issue is, over time, what are the key success factors to CBT? The United States Small Business Administration notes that $70 \%$ of all new businesses have a survival rate of at least 2 years, and this drops by half in the 5 th year and to $33 \%$ in the 10 th year. Only 25\% last more than 15 years (Hirsh 2014). This is in line with the observation by Dunn and Bradstreet (2011), who state that just half of all the new ventures will still be in business after 10 years and that the risk of export closure is highest during the firm's first 5 years of operations. In a pooled regression analysis, Esteve-Pérez et al. (2013) also found out that trading relationships by younger firms 
(up to 10 years old) last longer than those of older firms. Relationships are a lifeline to venture survival.

The most essential capabilities for successful export and import trading are knowledge and technological abilities (Sefalafala 2012). CBT is complex by nature because it requires the successful interpretation of legislations and regulations of different jurisdictions. As stated by Singh (2009), skills and knowledge are needed to succeed in undertaking risky business activities such as exporting. CBT is fraught with constraints. These constraints and the key skills are discussed next. The possession of these skills enhances business success.

\section{Skills, knowledge and cross-border trade}

The acquisition of relevant export skills and knowledge is key to succeeding in the export trade (Ibrahim 2004). Though it is generally believed that entrepreneurs are endowed with creativity and natural intelligence (Lewis 2011; Taruwinga 2011), export skills need to be learnt to enhance success in the foreign market. Embarking successfully on CBT is evidence of built-up capacity, available to enhance survival and competitiveness in the foreign market (Zahra, Ucbasaran \& Newey 2009). For example, foreign exposure and technical training are associated with successful export performance (Contractora \& Kundub 2004). According to Berthou and Vicard (2013), the costs associated with a given trade constraint decrease as export experience rises. This experience allows firms to develop skills and managerial systems that manage and overcome the barriers to international trade (Kneller 2011).

Firms normally accumulate experience and skills over time. As argued by Longenecker et al. (2014), most learning takes place during the establishment phase, but this declines gradually with time. However, efficiencies improve with time as the entity grows. Older firms boast of a better reputation and business network built over time and because of the cumulative experience they can better compete in the foreign markets. In other words, older firms tend to have more experience and to be more efficient than younger firms through learning-by-doing processes (Jongwanich \& Kohpaiboon 2008). Therefore, they are likely to perform better than those with less experience (Amornkitvikai et al. 2012; Damijan et al. 2007). The more efficient a firm is on the domestic front, the more it is likely to get into the export arena relative to the less efficient one. The issue then is whether the importance of knowledge and skills increases or diminishes with time?

Therefore, the study hypothesises that the importance of skills in sourcing markets and supplies significantly decreases as the export experience of the firm increases, Hypothesis 1a (HO1a). In this study, firm export experience was measured by the period the business (under the current owner) had been in CBT. Successful cross-border trading refers to operating a profitable business that has potential for growth.
It also hypothesises that the importance of financial management skills significantly decreases as the export experience of the firm increases, Hypothesis $1 \mathrm{~b}(\mathrm{HO} 1 \mathrm{~b})$, and that the importance of the knowledge and management of border issues significantly decreases as the export experience of the firm increases, Hypothesis 1c (HO1c).

\section{Support for cross-border trade}

Networks, government and banks should provide support for CBT. These networks serve as links to other new networks and facilitate the discovery and exploitation of new market opportunities (Sefalafala 2012). Networks are provided through family and friends as well as ethnic affiliations. Networks are social capital that small-scale traders use to secure trust and this helps to reduce risk. According to Granovetter (2002), they are nodes to data sources critical in foreign markets where the businesses enjoy little support from government. Takahashi (2009) points out that more experienced firms are likely to have built strong relationships with key publics; therefore, the adverse effects of possible constraints are minimised when compared to younger (less experienced) firms. Government agencies and financial institutions are usually critical support structures in exporting. However, support interventions by governments tend to be under-utilised (Chandra et al. 2001). The reasons advanced for this include the programmes being irrelevant or the SMMEs not being aware of the existence of such programmes. Vegholm and Silver (2008) note that most traders favour networking with financial institution managers who are most likely to assist them during times of trouble instead of the government programmes.

However, there is evidence of very low accessibility to loans by SMMEs (Makhubela, Nyapfungwe \& Dhliwayo 2015; Nkuah, Tanyeh \& Gaeten 2013). The importance placed on the assistance needed for CBT success is expected to change in line with the firm's export experience. For example, older firms have potentially less risk than new ones because new firms do not have the same legitimacy and links, experience and access to resources as older firms (GlobalEntrepreneurship Monitor 2010; Stokes, Wilson \& Mador 2010). It is hypothesised that the importance of support needed (1) to source markets and supplies (Hypothesis HO2a); (2) in funding (Hypothesis HO2b) and (3) in knowledge and management of border issues (Hypothesis HO2c) declines significantly as the experience of the firm increases.

\section{Constraints faced in cross-border trade}

Cross-border trading is a risky entrepreneurial endeavour because quite often the traders are operating illegally (Egbert 2006). Therefore, the traders lack formal protection because of the nature of their operations. Therefore, they become prone to exploitation by untrustworthy officials and business partners (Egbert 2006). All factors that constrain enterprises to organise and sustain operations in the external market are considered trade barriers (Leonidou 2004). These barriers may be from within or from outside of the firm 
(Tesform \& Lutz 2006). The internal constrains include lack of skills while the external ones include limited or lack of financial support and restrictive border laws (Mpinganjira 2011; Tesform \& Lutz 2006). The critical skills include leadership and knowledge of cross-border trading, especially during the growth stage where structural and contextual changes take place (Cope, Kempster \& Parry 2011).

As pointed out by Iyer (2010), the experience of the firm does not explain export intensity success. The ability of the firm to successfully manoeuvre within the constraints depends on its embedded knowledge and sustained experience. A firm's experience in a specific industry is a critical variable into measuring firm export success. The more export experience a firm has implies its success in having overcome a number of these obstacles (Global Entrepreneurship Monitor 2010; Takahashi 2009). Barriers to export and import differ from country to country and impact firms in different ways. Kneller (2011) notes that the relevance of a barrier depends on a single variable (the number of years exporting) and that no other firm-level aspects, for example, export intensity, research and development expenditure, nor industry-level variables, consistently relate to export constraints. A study by Kneller and Pisu (2006) shows that firms with different export experiences are affected differently by marketing barriers, but the effects of border regulations appear to be the same irrespective of the firms' export experience.

The constraints cross-border traders face are assumed to change with the firm's export experience. The newer, less experienced exporters will likely have a limited knowledge in export and import or the capacity to handle constraints. The same constrains would pose less threat to a more experienced firm. Barriers and therefore trade costs are higher in inexperienced firms (Levchenko, 2007). Hypothesis 3 stated that the importance of the constraint (1) supplies and markets (HO3a), (2) finance (HO3b) and (3) border management issues $(\mathrm{HO} 3 \mathrm{c})$ significantly decreased as export experience increases.

The next section outlines the research methodology. The research design, data collection instrument, sources of data and how the data were collected form part of the discussion.

\section{Research methodology}

The study is cross-sectional in design.

The sampling frame were the 10 SADC countries that were known to be doing business in South Africa. Currently, SADC has a membership of 15 member states. Judgemental sampling was used to decide on the sample size and to select respondents. The intention was to interview 20 traders from each of the 10 SADC member states. This was arrived at arbitrarily taking into account the capacity of the six data collectors and their ability to complete the collection in the planned 2 weeks. This would have resulted in a sample of 200 which was considered large enough to enable the required tests. Instead, data were collected with the aid of a structured questionnaire from 146 traders from 7 countries, namely, the Democratic Republic of Congo, Malawi, Mozambique, South Africa, Swaziland, Zambia and Zimbabwe. The SADC countries excluded in this choice were Tanzania, Mauritius, Namibia, Angola and Madagascar mainly because of distance and limited interaction with Gauteng Province, where most of the data would be collected. Respondents were chosen randomly with the basic criteria being cross-border trading and SADC citizenship. The traders were interviewed at different transport and trading nodes, which include taxi and bus termini, trade and wholesale complexes where traders source their goods and also the premises they operated from.

Data were collected by trained personnel at the different points identified. In the second part of the instrument, openended questions requesting traders to identify and rank the most important skills, support needed and the constraints in cross-border trading were asked. A total of 146 questionnaires were administered face to face and retained for analysis. All respondents were interviewed at different locations in South Africa.

\section{Findings and discussion}

The demographics of the respondents will be discussed first. The requirements and the constraints affecting success in CBT are analysed and recommendations are made. SPSS was used to analyse data. The study's hypotheses were tested using the chi-square method.

\section{Descriptive statistical analysis}

The findings indicate that $62 \%$ of the firms had been in CBT for a period of less than 5 years while $16 \%$ had been in the trade for less than 10 years. The remaining $22 \%$ had been in the trade for over 10 years. The result is in line with the finding by Dunn and Bradstreet (2011) and Hirsh (2014), which shows that the risk of failure of an export business is highest in the first 5 years and that only $25 \%$ of the business last for over 10 years. Though the reason for this may be complex to understand, it is clear to see that the more the firm experiences the higher the chances of survival.

\section{Key skills to succeed in cross-border trade}

The traders were requested to identify and rank the three most important skills in CBT. They ranked the following three as the most important:

Firstly, the sourcing of markets and supplies: this is the ability to identify potential suppliers and customers and to be able to establish and sustain business networks. Secondly, financial management skills: this is the ability to source funding for the business as well as to optimally apply funds in the running of the business. This includes management of working capital skills. Thirdly, the knowledge and management of border issues: this includes knowledge of import and export duties and tariffs as well as knowledge of the rules, regulations or incentives that apply to cross border trade. 
The finding that these three were the most important skills in CBT confirms findings by Berthou and Vicard (2013) which show market and marketing costs and legal, financial and tax regulations as the most common barriers. These skills are viewed as the most critical to resolve the identified barriers. The skills selected were then used to establish if their importance declined significantly as the exporter's experience increased. The findings reflected in Tables $1 \mathrm{a}, 1 \mathrm{~b}$ and $1 \mathrm{c}$ indicate that the importance of each of the skills did not significantly decline as the traders experience increased as reflected in the chi-square value $=0.22$ and $p=0.318$ (HO1a: sourcing of markets and supplies); chi-square value $=2.289$ and $p=0.989$ (HO1b: financial management skills) and a chisquare value $=3.158$ and $p=0.206$ (HO1c: knowledge and management of border issues).

With HO1a, HO1b and HO1c none are accepted. The differences do not significantly decline as export experience increases as was expected. The importance does not change whether export experience is less than 5 years or more than 10 years. Therefore, experience is not a predictor of the importance of skills required to succeed in cross-border trading.

The result implies that sourcing markets and supplies is crucial for young exporters. However, the importance of this factor would still be critical after 10 years when the enterprise may be expanding, or by now, well established. Therefore, the skills requirement will not diminish as experience increases. As more experience is acquired, the firm is likely to become bigger. Border issues, operations and financial management skill requirements will become more sophisticated. The increased capacities increase complexities overtime, which will also demand more advanced knowledge or expertise. As pointed out by Sefalafala (2012) and Singh (2009),

TABLE 1a: Chi-square tests: Export experience and supplies and markets.

\begin{tabular}{lccc}
\hline Variables & Value & Df & $\begin{array}{c}\text { Asymp. } \\
\text { Sig. (2-sided) }\end{array}$ \\
\hline Pearson chi-square & 2.289 & 2 & 0.318 \\
Likelihood ratio & 2.409 & 2 & 0.300 \\
Linear-by-linear association & 2.267 & 1 & 0.132 \\
No. of valid cases & 146 & - & - \\
\hline
\end{tabular}

Df, degrees of freedom.

TABLE 1b: Chi-square tests: Export experience and financial management.

\begin{tabular}{lccc}
\hline Variables & Value & Df & $\begin{array}{c}\text { Asymp. } \\
\text { Sig. (2-sided) }\end{array}$ \\
\hline Pearson chi-square & 0.022 & 2 & 0.989 \\
Likelihood ratio & 0.023 & 2 & 0.989 \\
Linear-by-linear association & 0.004 & 1 & 0.951 \\
No. of valid cases & 146 & - & - \\
\hline
\end{tabular}

Df, degrees of freedom.

TABLE 1c: Chi-square tests: Export experience and knowledge and management of border issues.

\begin{tabular}{lccc}
\hline Variables & Value & Df & $\begin{array}{c}\text { Asymp. } \\
\text { Sig. (2-sided) }\end{array}$ \\
\hline Pearson chi-square & 3.158 & 2 & 0.206 \\
Likelihood ratio & 3.112 & 2 & 0.211 \\
Linear-by-linear association & 2.084 & 1 & 0.149 \\
No. of valid cases & 146 & - & - \\
\hline
\end{tabular}

Df, degrees of freedom. trading across different jurisdictions is difficult whether the firm is relatively young or experienced.

The fact that trade rules and regulations and the competitive landscape are always changing requires firms to also continuously acquire and improve knowledge and skills. As SADC Today (2008) observes, traders lack reliable market information. They also lack management skills; therefore, they depend on fellow traders for support and information.

\section{Assistance in cross-border trading}

The following forms of assistance were identified and ranked by the traders as the most important for one to succeed in cross-border trading: (1) sourcing of markets and supplies, (2) funding and (3) general business management. An assessment was done to see if the importance of these factors changed with changes in export experience.

The study's second hypothesis was that the importance of assistance required to succeed in cross-border trading decreased significantly as export experience increased $(\mathrm{HOb})$. The results in Tables $2 \mathrm{a}, 2 \mathrm{~b}$ and $2 \mathrm{c}$ indicate that the importance of the assistance does not decrease significantly as the export experience increased, as shown by a $p$ value of 0.975 (HO2a: assistance in sourcing of markets and supplies), $p=0.628$ (HO2b: financial assistance) but does significantly decreases when it comes to assistance in general business management (HO2c) as shown by $p=0.025<0.05$. HO2c (assistance in general management) is accepted, while Hypotheses $\mathrm{HO} 2 \mathrm{a}$ and $\mathrm{HO}_{2} \mathrm{~b}$ are not accepted. The $\mathrm{HO} 2 \mathrm{c}$ result implies that the requirement for general management support declines significantly as firm experience increases. The need for financial assistance and for sourcing of supplies and markets does not significantly decrease with time or experience.

TABLE 2a: Marketing and supplies assistance: chi-square tests.

\begin{tabular}{lccc}
\hline Variables & Value & Df & $\begin{array}{c}\text { Asymp. } \\
\text { Sig. (2-sided) }\end{array}$ \\
\hline Pearson chi-square & 0.050 & 2 & 0.975 \\
Likelihood ratio & 0.050 & 2 & 0.975 \\
Linear-by-linear association & 0.028 & 1 & 0.867 \\
No. of valid cases & 146 & - & - \\
\hline
\end{tabular}

Df, degrees of freedom.

TABLE 2b: Financial assistance: chi-square tests.

\begin{tabular}{lccc}
\hline Variables & Value & Df & $\begin{array}{c}\text { Asymp. } \\
\text { Sig. (2-sided) }\end{array}$ \\
\hline Pearson chi-square & 0.930 & 2 & 0.628 \\
Likelihood ratio & 0.904 & 2 & 0.636 \\
Linear-by-linear association & 0.890 & 1 & 0.345 \\
No. of valid cases & 146 & - & - \\
\hline f & & &
\end{tabular}

Df, degrees of freedom.

TABLE 2c: Management assistance: chi-square tests.

\begin{tabular}{lccc}
\hline Variables & Value & Df & $\begin{array}{c}\text { Asymp. } \\
\text { Sig. (2-sided) }\end{array}$ \\
\hline Pearson chi-square & 7.392 & 2 & 0.025 \\
Likelihood ratio & 7.539 & 2 & 0.023 \\
Linear-by-linear association & 7.240 & 1 & 0.007 \\
No. of valid cases & 146 & - & - \\
\hline
\end{tabular}

Df, degrees of freedom. 
The result in $\mathrm{HO} 2 \mathrm{c}$ could be understood from the premise that the continued success of any business hinges on the quality of its management. It is assumed that the more experience or capacity an enterprise would have acquired, the more confident it would be about its capabilities, hence, the less management assistance it would need. In the absence of this capacity, the enterprise would most likely have long closed shop. The building of management capacity is an internal issue unlike funding, markets and supplies, which often involve inputs by external parties.

According to Chandra et al. (2001) less than 13\% of South African firms were aware of the different export incentive schemes available to help them. These programmes are set up by most SADC governments. In South Africa, government has many support schemes for SMME exporters. One reason given for poor reach was that the government bulletins (written) and Internet as a communication medium were not accessible to many traders. Assistance in funding and in growing markets remains high over the different export periods. Temtime, Chinyoka and Shenda (2004) point out that banks have been criticised for being insensitive to the SMME sector. They are accused of demanding strict collateral security and charging punitive interests rates (Vegholm \& Silver 2008).

However, it should be understood that banks are commercial entities that need to protect investor deposits and also maximise investor returns. An increase in demand from current markets and a need to establish new ones pushes the enterprise to seek additional funding from external sources, hence the need for continued financial support.

\section{Constraints in cross-border trade}

The most inhibitive constraints faced (in order of importance) were identified as the following: sourcing of markets and supplies, funding and border restrictions. This is in line with earlier findings by Berthou and Vicard (2013).

Hypothesis 3 (HO3) stated that the importance of the following constraints: markets and supplies (HO3a), financial $(\mathrm{HO} 3 \mathrm{~b})$ and border management issues (HO3c), declined significantly as firm export experience increased. As indicated in Tables 3a, 3b and 3c, the chi-square value $=2.057, p=0.357$ (HO3a); chi-square value $=0.79, p=0.961(\mathrm{HO} 3 \mathrm{c})$ and chisquare value $=0.633, p=0.729$ (HO3a), are all larger than $p>0.05$ and are all not significant. The importance of each constraint does not change significantly as firm experience accumulates. The results are in line with findings by Kneller and Pisu (2006), who found that in regressions where experience was an issue, the importance placed on a particular constraint declined as experience increased. However, the decline was not significant but complex because it was not linear.

Chiliya et al. (2011) and SARDC.Net (2008) indicate that among the many obstacles the traders encounter is lack of recognition of cross-border trading as a form of business.
TABLE 3a: Marketing constraint: chi-square tests.

\begin{tabular}{lccc}
\hline Variables & Value & Df & $\begin{array}{c}\text { Asymp. } \\
\text { Sig. (2-sided) }\end{array}$ \\
\hline Pearson chi-square & 2.057 & 2 & 0.357 \\
Likelihood ratio & 2.046 & 2 & 0.360 \\
Linear-by-linear association & 1.192 & 1 & 0.275 \\
No. of valid cases & 146 & - & - \\
\hline Df, degrees of freedom & & &
\end{tabular}

TABLE 3b: Finance constraint: chi-square tests.

\begin{tabular}{lccc}
\hline Variables & Value & Df & $\begin{array}{c}\text { Asymp. } \\
\text { Sig. (2-sided) }\end{array}$ \\
\hline Pearson chi-square & 0.079 & 2 & 0.961 \\
Likelihood ratio & 0.078 & 2 & 0.962 \\
Linear-by-linear association & 0.077 & 1 & 0.782 \\
No. of valid cases & 146 & - & - \\
\hline
\end{tabular}

Df, degrees of freedom.

TABLE 3c: Border constraints: chi-square tests.

\begin{tabular}{lccc}
\hline Variables & Value & Df & $\begin{array}{c}\text { Asymp. } \\
\text { Sig. (2-sided) }\end{array}$ \\
\hline Pearson chi-square & 0.633 & 2 & 0.729 \\
Likelihood ratio & 0.700 & 2 & 0.705 \\
Linear-by-linear association & 0.444 & 1 & 0.505 \\
No. of valid cases & 146 & - & - \\
\hline
\end{tabular}

Df, degrees of freedom.

This results in the criminalisation of trade, which leads to harassment and abuse by authorities. The granting of passports or visas is made very difficult, excessive tariffs are charged and goods are at times impounded. Traders are treated as smugglers, drug traffickers and are exposed to humiliating body searches and numerous check-points. Government policies have created a very unsupportive regulatory environment.

\section{Policy and practice implications}

The study's results imply that recommended interventions to help SMMEs in cross-border trading should be the same and should not take into account the experience of the firm. Firm experience should only be taken into account where skills in general management are concerned. All other recommended interventions are equally important irrespective of the firm's export experience or age. All stakeholders should ensure that appropriate interventions to assist the traders are properly effected.

\section{Small, micro and medium enterprises' support}

Literature shows that cross-border traders are not aware of the existence of support programmes put in place to assist them. However, it is not clear whether the programmes are relevant to the traders. Therefore, it is important for stakeholders to know what the most critical needs are (as identified in this study) and to know that the critical needs do not change at the different stages of an exporter's experience. The study's recommendations provide guidelines for appropriate interventions. One important implication from the study's finding is that small exporting firms get to a certain stage (experience level) where they are confident in their management capacity (skills) such that 
they do not require external assistance once that stage is reached.

The current developmental interventions should be communicated effectively to new and potential traders as well as existing ones. Potential traders should be motivated to join through support incentives. As shown by research, CBT plays a critical role in both individual firm, national and regional economic development. The SADC protocols and country-specific trade agencies should assist traders with market and procurement data. Both private and public sectors should have preferential procurement for crossborder traders. This should be buttressed by the necessary financial support packages. The SADC free-zone protocols should also be implemented in full in line with the structural support needed for the success of CBT. The support that the government offers is usually fragmented, making it difficult to ascertain its actual impact on the ground.

Governments need to come up with sustainable, integrated interventions that address the needs of the traders. The assistance needs continuous tracking and its impact has to be measured properly in the form of actual changes in individual businesses. SARDC.Net (2008) argues that ignoring CBT is counterproductive and constrains entrepreneurial citizens who choose to be involved in economic activities to empower themselves out of poverty. It is imperative that governments and other stakeholders view CBT with a positive attitude and use it as an instrument of economic empowerment.

\section{Skills}

The study shows that the importance placed on skills does not significantly change over the two periods surveyed. Interventions to provide identified critical skills are recommended. Training workshops that accommodate their trading patterns should be offered. An academic avenue (formal qualifications) that includes certificates, diplomas and degrees (classroom or online) in CBT could also be pursued.

As pointed out by Haahti et al. (2005), critical knowledge on exporting and foreign markets can also be acquired from individual and business networks as well as government institutions. The SMME sector cannot recruit and retain experienced and skilled export staff because these are easily snapped up by bigger more established entities who can afford them. Therefore, there is a need to capacitate the SMME sector to improve its competitiveness in both the domestic and the foreign markets (Zahra et al. 2009). CBT can be used as a launch pad for the internationalisation of the region's SMMEs.

\section{Constraints}

The major constraint identified by respondents was the sourcing of markets and supplies. This is not surprising given that the same factors were identified as a key area that traders required support in. The protocol calls for the harmonisation of the trading bloc's trade policies. This would address the issues such as the stringent visa requirements and the multiplicity of trading licences and permits (SARDC. Net 2008). For example, Lesser and Moisé-Leeman (2009) calls for the easing of border requirements so as to assist SMMEs who in most cases do not have the complex knowledge, structures and systems critical in the export trade.

Literature indicates that internationalisation usually improves competitiveness and growth of export firms. Formalisation reduces business risk and the cost of interventions by stakeholders. It is also likely to maximise production outputs. Border officials should be made to appreciate the economic importance of CBT. Border policies need to be formulated to ease and promote instead of inhibiting trade. An integrated political-economic approach of the recommended interventions that has a regional bias will address this constraint. This approach will also resolve the border issue constraint, which is a creation of governments who promote individual interests at the expense of regional economic and political integration. As argued by Sleuwaegen and Onkelinx (2010), only those domestic firms that are bigger and more efficient will likely go into exporting. Governments should remove barriers that mitigate against CBT so as to attract more SMMEs to join the export business and to internationalise operations.

All barriers that hinder CBT should be removed and incentives should be provided by different stakeholders to encourage SMMEs to internationalise. Trade promotes not only economic development but also social and political stability. Rules and regulations as well as the officials who apply them are government instruments to promote not only economic activity but also intra-SADC social and political integration. To maximise CBT performance, relevant training, technology and business linkages should be provided as part of business development (Goldberg \& Palladini 2008). The formalisation of the trade should be the bottom line for all traders. This would enable them to meet the one primary requirement for accessing most governments' incentive programmes.

\section{Conclusion}

The most inhibitive barriers and the most important skills as perceived by the traders themselves were identified. As a result, stakeholders that include existing and potential traders now know in which specific areas to intervene. The chances of success of these interventions are enhanced by taking firm experience into consideration. As shown in this study, the constraints faced and the skills and assistance required generally tend not to change over time. This implies that similar interventions are required over different periods of export operations.

The perceptions of cross-border traders are aggregated. These perceptions have not been tested to confirm whether the skills if present or the constraints if removed affect success in CBT. Only respondents trading in South Africa at the time 
of data collection were considered in this study. Cross-border trading taking place between other SADC countries was not part of this study. A more inclusive, representatively bigger sample comprising all intra-SADC trade is needed in a future study in order to have a more comprehensive picture of the trade in the region.

\section{Acknowledgements}

The author would like to acknowledge the Gauteng Department of Economic Development (GDED) for sponsoring (under a separate research project) the primary collection of the data used in this study.

The author would also like to extend his appreciation to the anonymous reviewers of this article for their invaluable inputs.

\section{Competing interests}

The authors declare that they have no financial or personal relationships which may have inappropriately influenced them in writing this article.

\section{References}

Ama, N.O., Mangadi, K.T. \& Ama, H.A., 2014, 'Characterization of informal crossborder traders across selected Botswana borders', International Journal of Management traders across selected Botswana bork

Amornkitvikai, Y., Harvie, C. \& Charoenrat, T., 2012, 'Factors affecting the export participation and performance of Thai manufacturing small and medium sized enterprises (SMEs)', 57th International Council for Small Business World Conference, Wellington, New Zealand, pp. 1-35, viewed 23 January 2015, from Conference, Wellington, New Zealand, pp. 1-35, viewed 23 January 2015, from $\mathrm{http}: / /$ seaanz.org/content/factors-affecting-expc
performance-thai-manufacturing-small-and-medium

Ayan, T.Y. \& Percin, S., 2005, 'A structural analysis of the determinants of export performance: Evidence from Turkey', Innovative Marketing 1(2), 106-120.

Bernard, A.B., Jensen, J.B., Redding, S.J. \& Schott, P.K., 2007, Firms in international trade, viewed 14 January 2015, from http://faculty.som.yale.edu/peterschott/ files/research/papers/jep_029.pdf

Bernard, A.B., Jonathan, E., Jensen, J.B. \& Kortum, S.S., 2003, 'Plants and productivity in international Trade', American Economic Review 93(4), 1268-1290. http:// dx.doi.org/10.1257/000282803769206296

Berthou, A. \& Vicard, V., 2013, Firms' export dynamics experience vs. size. The competitiveness research network, European Central Bank, viewed 12 July 2015, from http://www.ecb.europa.eu

Chandra, V., Moorty, L., Nganou, J.P., Rajaratnam, B. \& Schaefer, K., 2001, Constraints to growth and employment in South Africa, Report no: 2. Evidence from the small, medium and micro enterprise export survey, Informal Discussion Papers on Aspects of the South African Economy, Southern Africa Department, World Bank Washington, DC, viewed 23 July 2015, from http://www.essa.org.za/download/ wb/Chandra_SMME_DP15.pdf

Chiliya, N., Masocha, R. \& Zindiye, S., 2011, Challenges facing Zimbabwean cross border traders trading in South Africa: A review of literature, viewed 12 July 2014, from http://www.wbiconpro.com/224-Norman.pdf

Chiwara, L. \& Ndiaye, T., 2010, The contribution of women informal cross border traders to transform SADC economies, UNDP, viewed 12 April 2014, from www. sz.undp.org/.../UNDP_SZ_Organisational_Arrangement_for_Women

Contractora, F.J. \& Kundub, S., 2004, 'The role of export driven entrepreneurship in economic development: A comparison of software firm from India, China and Taiwan', Technological Forecasting and Social Change 71(8), 799-822. http://dx. doi.org/10.1016/j.techfore.2004.01.012

Cope, J., Kempster, S. \& Parry, K., 2011, 'Exploring distributed leadership in the small business context', International Journal of Management Reviews 13(3), 270-285. http://dx.doi.org/10.1111/j.1468-2370.2011.00307.x

Damijan, J., Polanec, S. \& Prašnikar, J., 2007, 'Self-selection, export market heterogeneity and productivity improvements: Firm level evidence from Slovenia', The World Economy 30(1), 135-158. http://dx.doi.org/10.1111/j.1467-9701.2007.00876.x

Devey, R. \& Valodia, I., 2009, Formal, informal economy linkages: What implications for South Africa, Working Paper 8, School of Developmental Studies, University of Kwazulu Natal, viewed 12 June 2014, from www. plaas.org.za/publications/wp/w/ formal-informal-economy-linkages-by-richard-devey-imraan-valodia/file

Dunn \& Bradstreet, 2011, Business failures and start-up analysis. Half-yearly results, viewed 20 April 2014, from http://www.dnb.com.au
Eder, M., Yakovlev, A. \& Çarkoglu, A., 2003, The suitcase trade between Turkey and Russia: Microeconomics and institutional structure, Working Paper WP4/2003/07, State University, Higher School of Economics, Moscow, viewed 12 April 2014, from https://www.hse.ru/data/2010/05/05/1216427500/WP4_2003_07.pdf

Egbert, H., 2006, 'Cross-border small-scale trading in South-Eastern Europe: Do embeddedness and social capital explain enough?' International Journal of Urban and Regional Research 30(2), 346-361. http://dx.doi.org/10.1111/j.1468-2427. 2006.00668.x

Esteve-Pérez, S., Requena-Silvente, R. \& Pallardó-Lopez, V.J., 2013, 'The firm duration of firm- destination export relationships: Evidence from Spain, 1997-2006', Economic Inquiry 51(1), 159-180. http://dx.doi.org/10.1111/j.1465-7295. 2012.00460.x

Facundo, A., Calvo Pardo, H.F., Corcos, G. \& Ornelas, E., 2010, 'Sequential exporting', Journal of International Economics 88(1), 17-31.

Global Entrepreneurship Monitor (GEM), 2010, 2010 Report on higher expectation entrepreneurship, viewed 01 June 2013, from http://www.gemconsortium.org

Goldberg, M. \& Palladini, E., 2008, Chile: A Strategy to promote innovative small and medium enterprises, The World Bank, Poverty Reduction and Economic Management Department Latin America Finance and Private Sector Unit, Policy Research Working Paper 4518, viewed 13 April 2014, from http://econ. worldbank.org

Granovetter, M., 2002, 'A Theoretical agenda for economic sociology', in M. Guillen, R. Collins, P. England \& M. Meyer (eds.), The economic sociology: Developments in an emerging field, pp. 35-59, Russell Sage, New York.

Haahti, A., Madupu, V., Yavas, U. \& Babakus, E., 2005, 'Cooperative strategy, knowledge intensity and export performance of small medium enterprises', Journal of World Business 40(2), 124-138. http://dx.doi.org/10.1016/j.jwb.2005.02.003

Haltiwanger, J., Ron, S.J. \& Javier, M., 2013, 'Who creates jobs? Small versus large versus young', Review of Economics and Statistics 95(2), 347-361. http://dx.doi. org/10.1162/REST_a_00288

Hirsh, L., 2014, Businesses that have high failure rates, viewed 20 May 2016, from http://smallbusiness.chron.com/businesses-high-failure-rates-61640.html

Ibrahim, M.H., 2004, 'A VAR Analysis of US and Japanese effects on Malaysian aggregate and sectoral output', International Journal of Applied Econometrics and Quantitative Studies 1(1), 5-28.

Iyer, K., 2010, 'The determinants of export-level export intensity in New Zealand agriculture and forestry', Economic analysis and Policy 40(1), 75-86. http://dx.doi org/10.1016/S0313-5926(10)50005-5

Jongwanich, J. \& Kohpaiboon, A., 2008, Export performance, foreign ownership, and trade policy regime: Evidence from Thai Manufacturing, ADB Economics Working Paper No. 140, Asian Development Bank, Metro Manila, Philippines, viewed 18 December 2014, from www.adb.org/sites/default/files/publication/.../economicswp140.pdf

Kneller, K., 2011, 'Barriers to exporting: What are they and who do they matter to?' The World Economy 34(6), 893-930. http://dx.doi.org/10.1111/j.1467-9701. 2011.01357.x

Kneller, R. \& Pisu, M., 2006, 'The role of experience in export market entry: Evidence for UK Firms', GTAP Working Paper 2006/48, University of Nottingham,
Nottingham, viewed 6 December 2014, from www.nottingham.ac.uk/gep/ Nottingham, viewed 6 December
documents/papers/2007/07-12.pdf

Leonidou, L.C., 2004, 'An analysis of the barriers hindering small business export development', Journal of Small Business Management 42(3), 279-302. http:// development', Journal of Small Business Manag

Lesser, C. \& Moisé-Leeman, E., 2009, Informal cross border trade and trade facilitation reform in Sub Saharan Africa final report, OECD Trade Policy Working Paper No. 86, Trade and Agricultural Directorate Trade Committee: Working Party of the Trade Committee, viewed 15 November 2015, from http://www.oecd.org/trade

Levchenko, A., 2007, 'Institutional quality and international trade', Review of Economic Studies 74(3), 791-819. http://dx.doi.org/10.1111/j.1467-937X.2007.00435.x

Lewis, H., 2011, 'A model of entrepreneurial capability based on a holistic review of the literature from three academic domains', Industry \& Higher Education 25(6), 429-440. http://dx.doi.org/10.5367/ihe.2011.0071

Longenecker, J.G., Petty, J.W., Palich, L.E. \& Hoy, F., 2014, Managing small business: An entrepreneurial emphasis, 17th edn., Cengage Learning, South Western, Mason.

Makhubela, T., Nyapfungwe, B. \& Dhliwayo, S., 2015, 'Period in trading and sources of funding in South African micro enterprises', Investment Management and Financial Innovations 50(1), 290-298.

Manyathela, C., 2016, 'New threats to close Beit bridge border post over imports ban', Eyewitness News, viewed 25 July 2016, from http://ewn.co.za/2016/07/19/Newthreats-to-close-Beitbridge-border-over-imports-ban.

Melitz, M., 2003, 'The impact of trade on intra-industry reallocations and aggregate industry productivity', Econometrica 71(6), 1695-1725. http://dx.doi.org/10. 1111/1468-0262.00467

Mpinganjira, M., 2011, 'Perceived benefits and barriers to export involvement: Insights from non-exporters', African Journal of Business Management 5(22), 9116-9124.

Muûls, M. \& Pisu, M., 2009, 'Imports and exports at the level of the firm: Evidence from Belgium', World Economy 32(5), 692-734. http://dx.doi.org/10.1111/j.1467 9701.2009.01172.x

Nkuah, J., Tanyeh, J.P. \& Gaeten, K., 2013, 'Financing Small and Medium Enterprises (SMES) in Ghana: Challenges and determinants in Accessing bank credit', International Journal of Research in Social Sciences 2(3), 12-25.

Ottaviano, G. \& Martincus, C.V., 2011, 'SMEs in Argentina: who are the exporters?', Small Business Economics 37, 341-361. http://dx.doi.org/10.1007/s11187-0099244-0 
SADC Today, 2008, 'Cross border trade is booming across Southern Africa - study', 10(5), viewed 12 August 2014, from http://www.sardc.net/editorial/sadctoday/ documents/v10n5.pdf

SARDC.Net, 2008, Optimising regional integration in Southern Africa: Assessing informal cross border trade in SADC, viewed 12 August 2013, from http://www. mail.sardc.net/books/ICBTReport/index.php

Sefalafala, M.R., 2012, 'Investigating entrepreneurial intensity and capability among South African export firm', Unpublished Master of Management, University of the Witwatersrand, Johannesburg, viewed 16 April 2015, from www.wiredspace.wits. ac.za/bitstream/handle/../research\%20report\%20MS.pdf

Singh, D.A., 2009, 'Export performance of emerging markets', International Business Review 18(4), 321-330. http://dx.doi.org/10.1016/j.ibusrev.2009.03.002

Sleuwaegen, L.E. \& Onkelinx, J., 2010, Internationalization strategy and performance of small and medium sized enterprises, viewed 14 April 2014, from https://papers. ssrn.com/sol3/papers.cfm?abstract_id=1750048

Soontiëns, W., 2002, 'Managing international trade: An analysis of South African SMEs and regional firms', Management Decision 40(7), 710-719. http://dx.doi.org/10. $1108 / 00251740210438544$

Southern Africa Trust, 2008, Informal Cross-Border Trade in SADC, Consultation and planning Workshop, viewed 7 May 2013, from www.southernafricatrust.org/.../ ICBT\%20Workshop\%20Report.pdf

Stokes, D., Wilson, N. \& Mador, M., 2010, Entrepreneurship, Cengage Learning, London.

Takahashi, S.IY., 2009, 'Entrepreneurs as decisive human resources and business. Performance for the Lao SMEs', Chinese Business Review 8(7), 29-47.
Taruwinga, P., 2011, The influence of cultural factors on successful succession in Indian South African family owned businesses and American family owned businesses,
UNISA, South Africa, viewed 10 May 2013, from http://uir.unisa.ac.za/bitstream/ handle/10500/5453/thesis_taruwinga_.pdf

Tchouassi, G. \& Njikam, O., 2011, 'Women in informal cross-border trade: Empirical evidence from Cameroon', International Journal of Economics and Finance 3(3), 202-213.

Temtime, Z.T., Chinyoka, S.V. \& Shenda, J.P.W., 2004, 'A decision tree approach for integrating small business assistance schemes', Journal of Management Development 23(6), 653-578. http://dx.doi.org/10.1108/02621710410541132

Tesform, G. \& Lutz, C., 2006, 'A classification of export marketing problems of small and medium sized manufacturing firm in developing countries', International Journal of Emerging Markets 1(3), 262-281. http://dx.doi.org/10.1108/17468800610674480

The Citizen, 2016, Beit bridge border post burns in anger at Zim, viewed 20 July 2016, from http://citizen.co.za/1187109/beitbridge-border-post-burns-in-anger-at-zim/

Unwomen.org, 2010, Unleashing the potential of women informal cross border traders to transform Intra-African trade, viewed 18 August 2014, from http:// www.unwomen.org/en/digital-library/publications/2010/3/unleashing-thepotential-of-women-informal-cross-border-traders-to-transform-intra-africantrade\#sthash.DB506Q53.dpuf

Vegholm, F. \& Silver, L., 2008, 'The impact of corporate fairness on the bank-SME relationship', Journal of Financial Regulation and Compliance 16(4), 352-364. http://dx.doi.org/10.1108/13581980810918413

Zahra, S.A., Ucbasaran, D. \& Newey, L.R., 2009, 'Social knowledge and SMEs innovative gains from internationalisation', European Management Review 6(2), 81-93. http://dx.doi.org/10.1057/emr.2009.6 